Article

\title{
Aqueous asymmetric aldol reaction catalyzed by nanomagnetic solid acid $\mathrm{SO}_{4}{ }^{2-} / \mathrm{Zr}(\mathrm{OH})_{4}-\mathrm{Fe}_{3} \mathrm{O}_{4}$
}

\author{
Tao Wu, Jingwei Wan, Xuebing Ma* \\ School of Chemistry and Chemical Engineering, Southwest University, Chongqing 400715, China
}

\section{A R T I C L E I N F O}

Article history:

Received 13 July 2014

Accepted 2 September 2014

Published 20 March 2015

\section{Keywords:}

Solid acid catalyst

Magnetism

Aldol reaction

Asymmetric catalysis

Aqueous phase

\begin{abstract}
A B S T R A C T
Magnetic solid acid catalysts $\mathrm{SO}_{4}{ }^{2-} / \mathrm{Zr}(\mathrm{OH})_{4}-\mathrm{Fe}_{3} \mathrm{O}_{4}$ were prepared using magnetic $\mathrm{Fe}_{3} \mathrm{O}_{4}$ nanoparticles, $\mathrm{ZrOCl}_{2} \cdot 8 \mathrm{H}_{2} \mathrm{O}$, and sulfuric acid as starting materials in the calcination temperature range $110-650{ }^{\circ} \mathrm{C}$. The properties of the magnetic solid acid, such as loaded $\mathrm{SO}_{4}{ }^{2-}$ content, acid distribution, surface morphology, and porous structure, were characterized. In the aqueous asymmetric aldol reaction of various benzaldehydes with strong electron-withdrawing groups $\left(\mathrm{R}=\mathrm{NO}_{2}\right.$ and $\left.\mathrm{CN}\right)$, good to excellent catalytic performance $(83 \%-100 \%$ yield, $86.0 \%-95.6 \%$ ee anti, and anti/syn = 88-96/12-4) was achieved. These nanomagnetic solid acids can be quantitatively recycled from the reaction mixture using an external magnet and reused five times without significant loss of catalytic activity.
\end{abstract}

(C) 2015, Dalian Institute of Chemical Physics, Chinese Academy of Sciences. Published by Elsevier B.V. All rights reserved.

\section{Introduction}

The asymmetric aldol reaction is one of the most important $\mathrm{C}-\mathrm{C}$ bond-forming reactions and creates the optically active $\beta$-hydroxy carbonyl structural unit found in many natural products and drugs [1-4]. Most asymmetric aldol reactions involve the directed aldol reaction in the presence of acidic promoters, including organic and inorganic acids, which are used to activate aldehydes electrophilically. Unfortunately, organic acids such as $\mathrm{TfOH}$ and $\mathrm{F}_{3} \mathrm{CCO}_{2} \mathrm{H}$ have high solubility in the organic phase, which results in impurities in the catalytic products owing to difficult separation. Furthermore, liquid inorganic acids are highly corrosive to industrial equipment. Therefore, the choice of the solid acid in the aldol reaction is a crucial decision [5-10].

Magnetic nanoparticles (MNPs) with large specific surface areas and good textural properties are currently an area of extensive research, particularly for applications in catalysis and adsorption processes owing to their unique superparamagnetism, low toxicity, simple preparation, low cost, and ease of recovery [11-13]. To combine the advantages of MNPs and solid acids, magnetic solid acids have been developed and widely applied in catalytic nitration [14], the Hantzsch reaction [15], esterification [16,17], hydrolysis reactions [18,19], the acetal reaction of benzaldehyde with ethylene glycol [20], and coupling reactions of aryl bromides with heterocycles [21]. However, the application of magnetic solid acids in asymmetric catalytic reactions is seldom reported.

In this paper, the nanomagnetic solid acids $\mathrm{SO}_{4}{ }^{2-} / \mathrm{Zr}(\mathrm{OH})_{4-}$ $\mathrm{Fe}_{3} \mathrm{O}_{4}$ [22-24] were applied to the asymmetric aldol reaction of cyclohexanone with various substituted benzaldehydes for the first time. Good to excellent catalytic performance for the benzaldehydes with strong electron-withdrawing groups $(83 \%-$ $100 \%$ yield, $86.0 \%-95.6 \%$ ee anti, and anti/syn $=88-96 / 12-4$ ) was satisfactorily achieved. These magnetic solid acids can be easily recovered in quantitative yield using an external magnet

*Corresponding author. Tel/Fax:+86-23-68253237; E-mail: zcj123@swu.edu.cn

This work was supported by the National Natural Science Foundation of China (21071116).

DOI: 10.1016/S1872-2067(14)60222-9 | http://www.sciencedirect.com/science/journal/18722067 | Chin. J. Catal., Vol. 36, No. 3, March 2015 
and possessed good tolerance in catalytic cycles with no significant loss of catalytic performance.

\section{Experimental}

\subsection{Preparation of nanomagnetic solid acid $\mathrm{SO}_{4}{ }^{2-} / \mathrm{Zr}(\mathrm{OH})_{4}-\mathrm{Fe}_{3} \mathrm{O}_{4}$}

The suspension of nano- $\mathrm{Fe}_{3} \mathrm{O}_{4}(2.32 \mathrm{~g}, 10.0 \mathrm{mmol}$, Aladdin, $99.5 \%)$ in distilled water $(20 \mathrm{~mL})$ was well stirred at $65^{\circ} \mathrm{C}$, and aqueous $\mathrm{ZrOCl}_{2} \cdot 8 \mathrm{H}_{2} \mathrm{O}$ solution (20 mL, Aladdin, 99.9\%) with molar ratios of $\mathrm{ZrOCl}_{2} \cdot 8 \mathrm{H}_{2} \mathrm{O}: \mathrm{Fe}_{3} \mathrm{O}_{4}=0.2,0.5,1.0,2.0$, or 5.0 was added dropwise. The $\mathrm{pH}$ of the reaction medium was adjusted to 13 by ammonia spirit and stirred for another $4 \mathrm{~h}$. The supernatant was decanted by magnetic separation using an external magnet, and the obtained magnetic solids $\mathrm{Zr}(\mathrm{OH})_{4} / \mathrm{Fe}_{3} \mathrm{O}_{4}$ were washed with distilled water until the solution was neutral and no $\mathrm{Cl}^{-}$ions were present and dried at $110{ }^{\circ} \mathrm{C}$ in vacuo. After three nitrogen replacement, grinding, immersing in $0.5 \mathrm{~mol} / \mathrm{L}$ sulfuric acid for $3 \mathrm{~h}$, and separating using an external magnet, the samples were dried at $110{ }^{\circ} \mathrm{C}$ to obtain nanomagnetic solid acids, which were designated as $\mathrm{SZF}_{1-5}$ for $\mathrm{ZrOCl}_{2} \cdot 8 \mathrm{H}_{2} \mathrm{O}: \mathrm{Fe}_{3} \mathrm{O}_{4}$ ratios of $0.2,0.5,1.0,2.0$, and 5.0 , respectively $[25,26]$. $\mathrm{SZF}_{3}$ was calcined in a muffle furnace at 300 or $650{ }^{\circ} \mathrm{C}$ for $3 \mathrm{~h}$ to give the nanomagnetic solid acids $\mathrm{SZF}_{3}-300$ and $\mathrm{SZF}_{3}-650$, respectively.

\subsection{Characterization of catalysts}

Magnetic hysteresis loops were measured on a vibrating sample magnetometer (VSM, HH-15, China) using $\mathrm{Ni}$ as the standard substance. The powder was strongly pressed and fixed in a small cylindrical plastic box for the magnetization measurements. Thermogravimetry-differential thermal analysis (TG-DSC) spectra of the as-synthesized samples were measured on an SBTQ600 thermal analyzer (TA, USA) with a heating rate of $20{ }^{\circ} \mathrm{C} / \mathrm{min}$ from 40 to $800{ }^{\circ} \mathrm{C}$ under $\mathrm{N}_{2}(100$ $\mathrm{mL} / \mathrm{min}$ ). The total acidity of the samples was determined by temperature-programmed desorption (TPD) of $\mathrm{NH}_{3}$. The measurements were carried out by an automatic TPD apparatus (PCA-1200, China). The sample was kept at $50{ }^{\circ} \mathrm{C}$ for 60 min in a flow of $\mathrm{NH}_{3}$. The amount of desorbed $\mathrm{NH}_{3}$ was determined after heating the sample up to $700{ }^{\circ} \mathrm{C}$ with a heating rate of $10{ }^{\circ} \mathrm{C} / \mathrm{min}$. $\mathrm{N}_{2}$ adsorption-desorption analysis was performed at $-196^{\circ} \mathrm{C}$ on an Autosorb-1 apparatus (Quantachrome, USA). All samples were degassed at $130{ }^{\circ} \mathrm{C}$ for $12 \mathrm{~h}$ before measurements, and the surface area and pore size distribution were calculated by the BET and BJH models, respectively. After being well-dispersed in water ( $10 \mathrm{mg}$ sample in $10 \mathrm{~mL}$ of $\mathrm{H}_{2} \mathrm{O}$ ) for 10 min under ultrasonic irradiation, sputtered over copper wire, and evaporated under infrared radiation for $10 \mathrm{~min}$, the as-synthesized samples were observed by transmission electron microscopy (TEM) using a JEM 2100 transmission electron microscope under an accelerating rate voltage of $200 \mathrm{kV}$ to show their surface morphologies (JEOL, Japan).

\subsection{Determination of $\mathrm{SO}_{4}{ }^{2-}$ content in nanomagnetic solid acid}

Accurately weighed nanomagnetic solid acid (100.0 mg) was soaked in $6 \mathrm{~mol} / \mathrm{L} \mathrm{HCl} \mathrm{(50} \mathrm{mL)} \mathrm{under} \mathrm{vigorous} \mathrm{stirring} \mathrm{for}$ $3 \mathrm{~h}$ and filtered. Saturated $\mathrm{BaCl}_{2}$ was added to the filtrate and $\mathrm{BaSO}_{4}$ precipitated out. After $\mathrm{BaSO}_{4}$ was filtered, dried under reduced pressure, and accurately weighed, the $\mathrm{SO}_{4}{ }^{2-}$ content was calculated.

\subsection{General asymmetric aldol reaction}

9-Amino-9-deoxy-epi-cinchonidine (epi-CDNH 2$)$ was prepared according to a literature procedure [27]. In a vial $(25 \mathrm{~mL})$, the mixture of nanomagnetic solid acid $\mathrm{SZF}_{3}$ (35.0 mg), epi-CDNH $\mathrm{C}_{2}$ (11.0 mg, $0.0375 \mathrm{mmol}$ ), cyclohexanone $(0.98 \mathrm{~g}$, $10.0 \mathrm{mmol}$, Adamas-beta, 99.5\%), and deionized water (2.0 $\mathrm{mL}$ ) was stirred at room temperature for $15 \mathrm{~min}$. Then, p-nitrobenzaldehyde (76 mg, $0.50 \mathrm{mmol}$, Adamas-beta, 99\%) was added and allowed to react at $25^{\circ} \mathrm{C}$ for $48 \mathrm{~h}$. After the reaction was complete, the $\mathrm{SZF}_{3}$ catalyst was magnetically separated using an external magnet and directly reused in the next experiment. The resulting reaction mixture was extracted with ethyl acetate $(3 \times 20 \mathrm{~mL})$. The combined organic phases were dried over anhydrous $\mathrm{Na}_{2} \mathrm{SO}_{4}$ and evaporated under reduced pressure to give the crude product, which was purified by flash column chromatography eluted with petroleum ether/ethyl acetate $(\mathrm{v} / \mathrm{v}=10 / 1$ to $2 / 1)$ to give pure 2-(hydroxy(4-methoxyphenyl)methyl)cyclohexanone. The anti/syn (Dr) ratio was determined by ${ }^{1} \mathrm{H}$ NMR in $\mathrm{CDCl}_{3}$, in which the chemical shifts of syn- and anti-CHOH protons were at $\delta=5.32 \mathrm{ppm}(\mathrm{d})$ with ${ }^{3} \mathrm{~J}=$ $1.3 \mathrm{~Hz}$ and $\delta=4.74 \mathrm{ppm}(\mathrm{d})$ with ${ }^{3} J=8.8 \mathrm{~Hz}$, respectively. The enantiomeric excess (ee) was determined by high-performance liquid chromatography (HPLC) (Agilent Technologies 1200 Series) with a $254 \mathrm{~nm}$ UV-vis detector using a Daicel chiralpak Chiral OD column ( $4.6 \mathrm{~mm} \times 250 \mathrm{~mm})$, eluting with $n$-hexane/ iso-propanol $(95 / 5)$ with a flow rate of $0.5 \mathrm{~mL} / \mathrm{min}$ at $20^{\circ} \mathrm{C}$.

\section{Results and discussion}

\subsection{Chemical composition of nanomagnetic solid acid}

The chemical compositions of the magnetic solid acids $\mathrm{SZF}_{1-5}$ are listed in Table 1. Although the molar ratios of $\mathrm{ZrOCl}_{2}: \mathrm{Fe}_{3} \mathrm{O}_{4}$ in the preparation of $\mathrm{Zr}(\mathrm{OH})_{4}-\mathrm{Fe}_{3} \mathrm{O}_{4}$ varied greatly in the range $0.2-5.0$, the formed $\mathrm{Zr}(\mathrm{OH})_{4}$ could be loaded onto nano- $\mathrm{Fe}_{3} \mathrm{O}_{4}$ in $72 \%-75 \%$ yield. The content of $\mathrm{Zr}(\mathrm{OH})_{4}$ in $\mathrm{SZF}_{1-5}$ determined by the inductively coupled plasma (ICP) method increased from $13.9 \%$ to $71.2 \%$ with the increasing

Table 1

Chemical compositions of the various magnetic solid acids.

\begin{tabular}{lcccc}
\hline Entry & Catalyst & $\begin{array}{c}\text { Molar ratio of } \\
\mathrm{ZrOCl}_{2}: \mathrm{Fe}_{3} \mathrm{O}_{4}\end{array}$ & $\begin{array}{c}\text { Loaded } \mathrm{Zr}(\mathrm{OH})_{4} \\
\text { (wt\%) }\end{array}$ & $\begin{array}{c}\mathrm{SO}_{4}^{2-} \text { content } \\
\text { (wt\%) }\end{array}$ \\
\hline 1 & $\mathrm{SZF}_{1}$ & $1: 5$ & 13.9 & 6.8 \\
2 & $\mathrm{SZF}_{2}$ & $1: 2$ & 20.3 & 14.3 \\
3 & $\mathrm{SZF}_{3}$ & $1: 1$ & 33.9 & 20.7 \\
4 & $\mathrm{SZF}_{4}$ & $2: 1$ & 50.1 & 17.2 \\
5 & $\mathrm{SZF}_{5}$ & $5: 1$ & 71.2 & 12.3 \\
\hline
\end{tabular}


molar ratio of $\mathrm{ZrOCl}_{2}: \mathrm{Fe}_{3} \mathrm{O}_{4}$. It is noteworthy that the $\mathrm{SO}_{4}{ }^{2-}$ contents in the magnetic solid acids $\mathrm{SZF}_{1-5}$ showed a close relationship with the loaded $\mathrm{Zr}(\mathrm{OH})_{4}$. The immersed $\mathrm{SO}_{4}{ }^{2-}$ contents in $\mathrm{SZF}_{1-5}$ first increased with increasing loaded amount of $\mathrm{Zr}(\mathrm{OH})_{4}$. However, when the loaded $\mathrm{Zr}(\mathrm{OH})_{4}$ exceeded 33.9\%, the $\mathrm{SO}_{4}{ }^{2-}$ content gradually decreased owing to the accumulation of $\mathrm{Zr}(\mathrm{OH})_{4}$ on the outer surface of nano- $\mathrm{Fe}_{3} \mathrm{O}_{4}$.

\subsection{Magnetic properties}

The magnetic properties of the representative solid acids $\mathrm{SZF}_{1}, \mathrm{SZF}_{3}$, and $\mathrm{SZF}_{3}$ ' (SZF 3 reused five times) were examined through vibrating sample magnetometry. Their hysteresis loops at room temperature are shown in Fig. 1. VSM analysis showed that the magnetic solid acids $\mathrm{SZF}_{1}, \mathrm{SZF}_{3}$, and $\mathrm{SZF}_{3}$ ' possessed saturated magnetization values of 55.58, 39.21, and $46.44 \mathrm{emu} / \mathrm{g}$, respectively. The saturated magnetization values of $\mathrm{SZF}_{1}, \mathrm{SZF}_{3}$, and $\mathrm{SZF}_{3}$ ' were all sufficiently high to meet the needs of magnetic separation. The zero coercivity and resonance of each magnetization loop confirmed the superparamagnetism behavior at $25^{\circ} \mathrm{C}$ for all of the samples, which is very beneficial for the catalyst's rapid dispersion and magnetic separation. Unexpectedly, the magnetic susceptibility of $\mathrm{SZF}_{3}{ }^{\prime}$ increased from 39.21 to $46.44 \mathrm{emu} / \mathrm{g}$. The most likely reason for this phenomenon is the decrease in $\mathrm{SO}_{4}{ }^{2-}$ content from 20.7 $\mathrm{wt} \%\left(\mathrm{SZF}_{3}\right)$ to $12.8 \mathrm{wt} \%\left(\mathrm{SZF}_{3}{ }^{\prime}\right)$, which was verified by the decrease in the catalytic performance.

\subsection{TG analysis}

Using solid acid $\mathrm{SZF}_{3}$ as an example, the thermal decomposition was characterized by TG-DSC. From the TG-DSC results shown in Fig. 2, there are three types of peaks for $\mathrm{SZF}_{3}$. An endothermic peak with a gradual weight loss of $6.08 \%$ below $200{ }^{\circ} \mathrm{C}$, which was verified by the DSC curve, was mainly attributed to desorption of surface-bound or intercalated water in the pores. Another gradual weight loss peak of $2.41 \%$ at 200-600 ${ }^{\circ} \mathrm{C}$ resulted from the dehydration of $\mathrm{Zr}(\mathrm{OH})_{4}$ to form amorphous $\mathrm{ZrO}_{2}$ [28] and the transformation of zirconia from

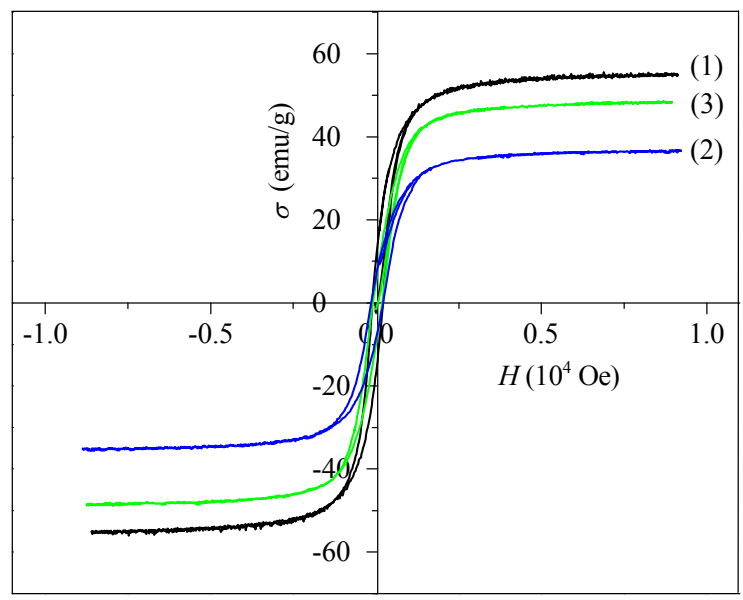

Fig. 1. Magnetization curves of the nanomagnetic solid acids (1) $\mathrm{SZF}_{1}$, (2) $\mathrm{SZF}_{3}$, and (3) $\mathrm{SZF}_{3}$ '.

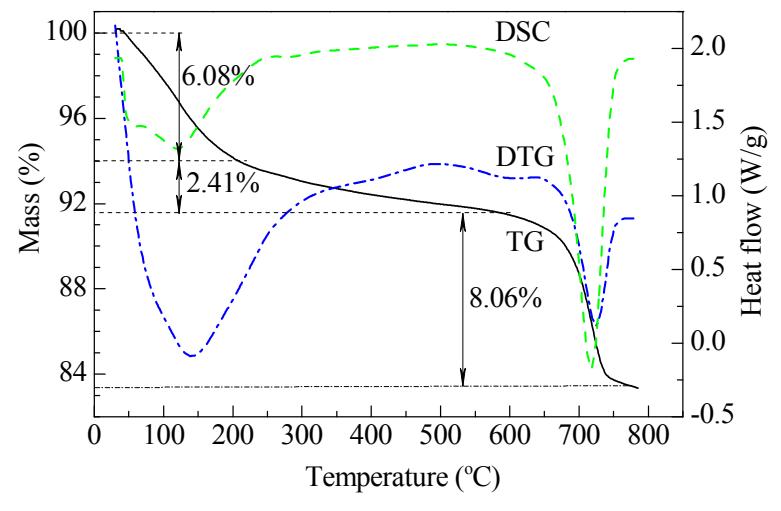

Fig. 2. TG-DSC curves of magnetic solid acid $\mathrm{SZF}_{3}$.

the tetragonal to the monoclinic phase [29]. Accompanied by an endothermic peak centered at $721^{\circ} \mathrm{C}$ in the DSC curve, the peak with a sharp weight loss of $8.06 \%$ at $600-780{ }^{\circ} \mathrm{C}$ corresponded to the removal of the $\mathrm{SO}_{4}{ }^{2-}$ group [14].

\section{4. $\mathrm{NH}_{3}-\mathrm{TPD}$ analysis}

The $\mathrm{NH}_{3}$-TPD profiles of the magnetic solid acids $\mathrm{SZF}_{3}$, $\mathrm{SZF}_{3}-300$, and $\mathrm{SZF}_{3}-650$ are shown in Fig. 3. Magnetic solid acid $\mathrm{SZF}_{3}$ with $0.952 \mathrm{mmol} / \mathrm{g}$ acidity showed a broad $\mathrm{NH}_{3}$ desorption peak, including four peaks centered at $146,257,389$, and $539{ }^{\circ} \mathrm{C}$, which indicated that the surface acid strengths were not homogeneously distributed. In general, the broad $\mathrm{NH}_{3}$ desorption peak was divided into two types of desorption peaks based on Gaussian fitting: the first broad medium temperature (MT) desorption signal in the range $100-300{ }^{\circ} \mathrm{C}$, corresponding to $\mathrm{NH}_{3}$ adsorbed on the acid sites at medium strengths; and the second broad high-temperature (HT) peak in the range of $300-650{ }^{\circ} \mathrm{C}$, suggesting the presence of very strong acid sites [29]. Unfortunately, the MT and HT desorption signals of $\mathrm{SZF}_{3}-300$ and $\mathrm{SZF}_{3}-650$ sharply decreased with increasing calcination temperature from 110 to $650{ }^{\circ} \mathrm{C}$ for $3 \mathrm{~h}$. Especially for magnetic solid acid $\mathrm{SZF}_{3}-650$, little $\mathrm{NH}_{3}$ adsorption demonstrated weak acidity $(0.178 \mathrm{mmol} / \mathrm{g})$, which was also evidenced by its poor catalytic performance in the following asymmetric aldol reaction.

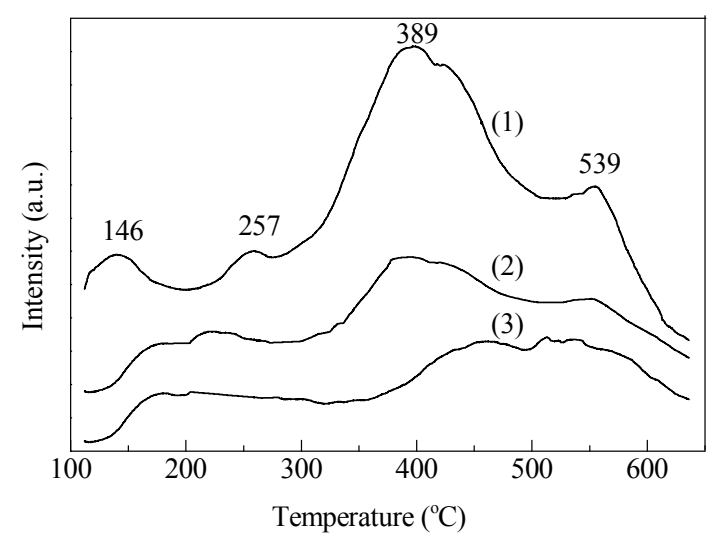

Fig. 3. $\mathrm{NH}_{3}-\mathrm{TPD}$ profiles of magnetic solid acids (1) $\mathrm{SZF}_{3}$, (2) $\mathrm{SZF}_{3}-300$, and (3) $\mathrm{SZF}_{3}-650$. 


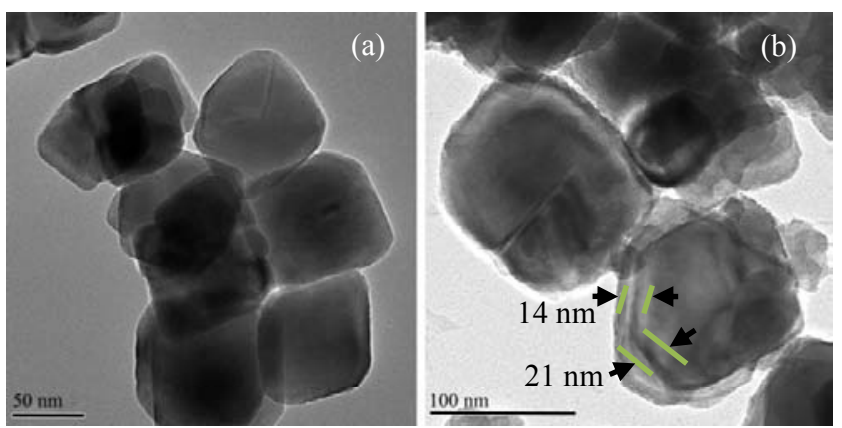

Fig. 4. TEM profiles of (a) nano- $\mathrm{Fe}_{3} \mathrm{O}_{4}$ and (b) magnetic solid acid $\mathrm{SZF}_{3}$.

\subsection{Surface morphology and porous structure}

The TEM images of nano- $\mathrm{Fe}_{3} \mathrm{O}_{4}$ and magnetic solid acid $\mathrm{SZF}_{3}$ are shown in Fig. 4. The micrograph of nano- $\mathrm{Fe}_{3} \mathrm{O}_{4}$ clearly shows uniform square crystallites of about 60-80 $\mathrm{nm}$ in diameter. After $\mathrm{Fe}_{3} \mathrm{O}_{4}$ was coated with $\mathrm{Zr}(\mathrm{OH})_{4}$ and immersed in 0.5 $\mathrm{mol} / \mathrm{L}$ sulfuric acid, the obtained magnetic solid acid $\mathrm{SZF}_{3}$ with 80-100 nm in diameter shows about 10-20 nm growth of particle size. The $\mathrm{N}_{2}$ adsorption-desorption isotherm of magnetic solid acid $\mathrm{SZF}_{3}$ (Fig. 5) is a type II isotherm in classic definitions, agreed well with the normal form obtained with a non-porous or macroporous adsorbent. This indicates that magnetic solid acid $\mathrm{SZF}_{3}$ was a typical microporous material, which was verified by its $\mathrm{BJH}$ pore size distribution plot (inset of Fig. 5). Based on the multipoint BET method and the BJH method, the BET specific surface area and pore volume of magnetic solid acid $\mathrm{SZF}_{3}$ were calculated to be $15.8 \mathrm{~m}^{2} / \mathrm{g}$ and $0.029 \mathrm{~mL} / \mathrm{g}$, respectively.

\subsection{XRD results}

Figure 6 shows the high-angle powder XRD patterns of nano- $\mathrm{Fe}_{3} \mathrm{O}_{4}, \mathrm{Zr}(\mathrm{OH})_{4}-\mathrm{Fe}_{3} \mathrm{O}_{4}$, and $\mathrm{SO}_{4}{ }^{2-} / \mathrm{Zr}(\mathrm{OH})_{4}-\mathrm{Fe}_{3} \mathrm{O}_{4}$. The XRD pattern of nano- $\mathrm{Fe}_{3} \mathrm{O}_{4}$ shows the typical peaks at $18.12^{\circ}, 30.08^{\circ}$, $35.45^{\circ}, 43.06^{\circ}, 53.49^{\circ}, 57.00^{\circ}, 62.62^{\circ}$, and $74.05^{\circ}$, which correspond to the (111) ( $d=5.68 \AA)$, (220) ( $d=3.44 \AA)$, (311) $(d=$ $2.94 \AA)$, (400) (d=2.44 $)$, (422) (d=1.99 $),(511)(d=1.87$

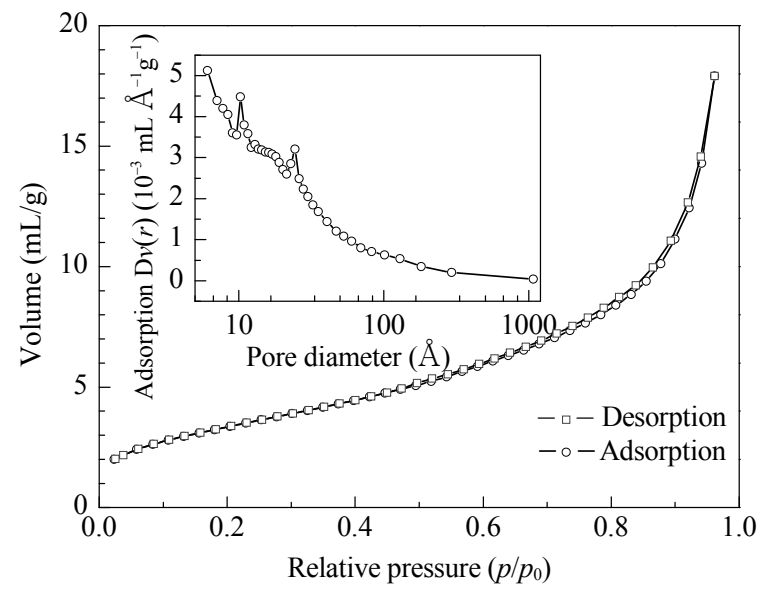

Fig. 5. $\mathrm{N}_{2}$ adsorption-desorption isotherms and pore size distribution (insert) of magnetic solid acid $\mathrm{SZF}_{3}$.

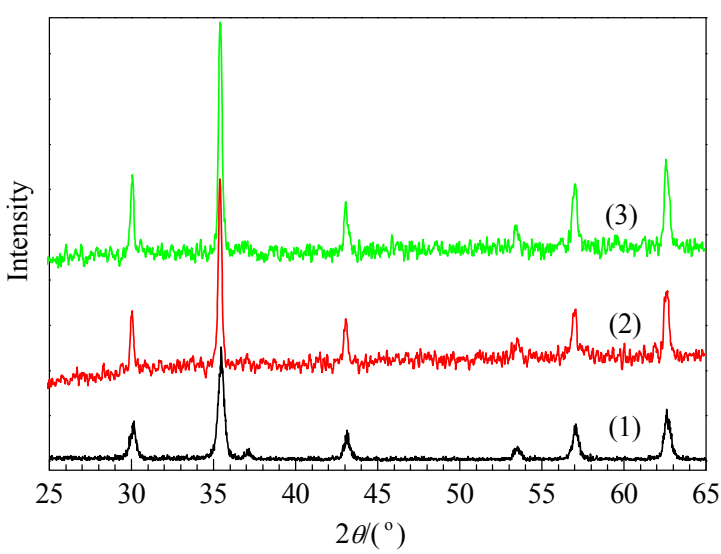

Fig. 6. Powder XRD patterns of (1) nano- $\mathrm{Fe}_{3} \mathrm{O}_{4},(2) \mathrm{Zr}(\mathrm{OH})_{4}-\mathrm{Fe}_{3} \mathrm{O}_{4}$, and (3) $\mathrm{SO}_{4}{ }^{2-} / \mathrm{Zr}(\mathrm{OH})_{4}-\mathrm{Fe}_{3} \mathrm{O}_{4}$.

$\AA ̊)$, (440) ( $d=1.72 \AA$ ), and (533) ( $d=1.48 \AA$ ) reflections, respectively [30]. After $\mathrm{Zr}(\mathrm{OH})_{4}$ and $\mathrm{SO}_{4}{ }^{2-}$ were consecutively loaded on nano- $\mathrm{Fe}_{3} \mathrm{O}_{4}$, there was no significant change in the various characteristic diffraction peaks, which indicated that $\mathrm{Zr}(\mathrm{OH})_{4}$ and $\mathrm{SO}_{4}{ }^{2-}$ were well-dispersed on/in the internal and external surfaces of nano- $\mathrm{Fe}_{3} \mathrm{O}_{4}$.

\subsection{Catalytic performance in asymmetric aldol reaction}

\subsubsection{Effect of reaction temperature and magnetic solid acids}

The asymmetric aldol reaction between 4-nitrobenzaldehyde and cyclohexanone was used as a model reaction to investigate the catalytic performance of the as-synthesized magnetic solid acids [31,32]. From Fig. 7, the catalytic reaction temperature had a great influence on the yield and enantioselectivity of the aldol adduct. With increasing reaction temperature, the yield of the aldol adduct increased, whereas the enantioselectivity markedly decreased. Considering these two contradictory factors, the optimal temperature of $25^{\circ} \mathrm{C}$ was chosen for the following screening tests.

Furthermore, the catalytic performance of various magnetic solid acids ( $\left.\mathrm{SZF}_{1-5}\right)$ in the aldol reaction of 4-nitrobenzaldehyde with cyclohexanone was evaluated, and the results are listed in Table 2. It was found that the $\mathrm{SO}_{4}{ }^{2-}$ content had a significant influence on the yield of the aldol adduct. Magnetic solid acid

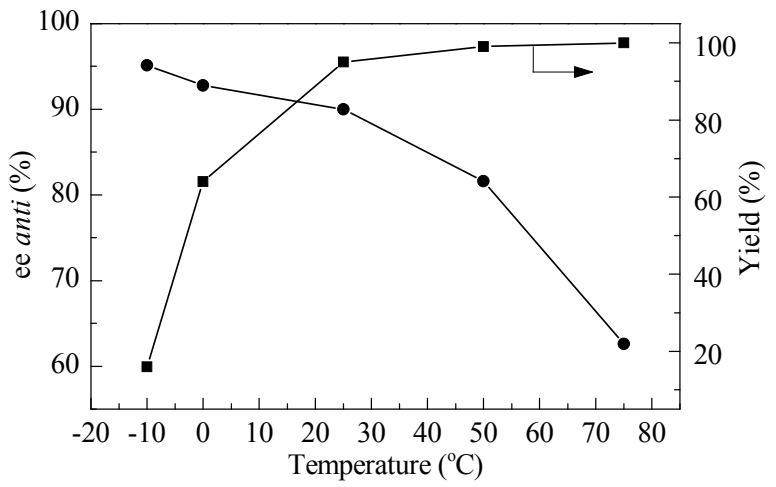

Fig. 7. Asymmetric aldol reaction of 4-nitrobenzaldehyde with cyclohexanone at different temperatures. 
Table 2

Asymmetric aldol reaction catalyzed by various magnetic solid acids.

\begin{tabular}{|c|c|c|c|c|}
\hline Entry & Catalyst & Isolated yield (\%) & ee $a n t i c(\%)$ & $\operatorname{Dr}(\text { anti/syn })^{c}$ \\
\hline 1 & $\mathrm{SZF}_{1}$ & 74 & 84.0 & $81 / 19$ \\
\hline 2 & $\mathrm{SZF}_{2}$ & 85 & 84.3 & $79 / 21$ \\
\hline 3 & $\mathrm{SZF}_{3}$ & 96 & 83.1 & $81 / 19$ \\
\hline 4 & $\mathrm{SZF}_{4}$ & 87 & 82.9 & $81 / 19$ \\
\hline 5 & $\mathrm{SZF}_{5}$ & 80 & 85.1 & $82 / 18$ \\
\hline 6 & - & 54 & 20.4 & $70 / 30$ \\
\hline 7 & $\mathrm{SZF}_{3}{ }^{\mathrm{a}}$ & $>99$ & 90.8 & $91 / 9$ \\
\hline 8 & TfOH ${ }^{b}$ & $>99$ & 96.8 & $93 / 7$ \\
\hline 9 & $\mathrm{Zr}(\mathrm{OH})_{4} / \mathrm{SO}_{4}{ }^{2-}$ & 98 & 91.2 & $90 / 10$ \\
\hline
\end{tabular}

Reaction conditions: Catalyst $(20.0 \mathrm{mg})$, epi- $\mathrm{CDNH}_{2}(11.0 \mathrm{mg}, 0.0375$ mmol), cyclohexanone (0.98 g, $10.0 \mathrm{mmol}), p$-nitrobenzaldehyde (76.0 $\mathrm{mg}, 0.5 \mathrm{mmol}), \mathrm{H}_{2} \mathrm{O}(2.0 \mathrm{~mL}), 25^{\circ} \mathrm{C}, 48 \mathrm{~h}$.

${ }^{a} \mathrm{SZF}_{3}$ (30.0 mg), $72 \mathrm{~h}$. ${ }^{\mathrm{b}}$ TfOH (10.0 mg), $12 \mathrm{~h}$.

'Determined by chiral HPLC (AD-H column).

$\mathrm{SZF}_{3}$ with $20.7 \% \mathrm{SO}_{4}{ }^{2-}$ content produced the highest yield (96\%, entry 3). However, the stereoselectivity was insensitive to the $\mathrm{SO}_{4}{ }^{2-}$ content. The enantioselectivity $(82.9 \%-85.1 \%$ ee anti) and diastereoselectivity (anti/syn = 79-82/21-18) changed little when the $\mathrm{SO}_{4}{ }^{2-}$ content varied in the range $6.8 \%-20.7 \%$. Unfortunately, in the absence of magnetic solid acid, the aldol reaction afforded unsatisfactory catalytic results ( $54 \%$ yield, $20 \%$ ee anti, and anti/syn $=70 / 30$, entry 6 ). In particular, compared with an organic acid (>99\% yield, $96.8 \%$ ee anti, and anti/syn $=93 / 7$ ), magnetic solid acid $\mathrm{SZF}_{3}$ gave similar diastereoselectivity (anti/syn $=91 / 9$ ) and lower enantioselectivity (90.8\% ee anti) in excellent yield (>99\%) (entries 7 and 8). Considering the possible effect of the bonding interaction between $\mathrm{Zr}(\mathrm{OH})_{4}$ and $\mathrm{Fe}_{3} \mathrm{O}_{4}$ on the catalytic performance, $\mathrm{Zr}(\mathrm{OH})_{4} / \mathrm{SO}_{4}{ }^{2-}$ was prepared according to the same procedure as $\mathrm{SZF}_{3}$ in the absence of $\mathrm{Fe}_{3} \mathrm{O}_{4}$. A similar yield and stereoselectivity of aldol products were obtained (entry 9), which indicated that the bonding interaction between $\mathrm{Zr}(\mathrm{OH})_{4}$ and $\mathrm{Fe}_{3} \mathrm{O}_{4}$ had little effect on the catalytic performance.

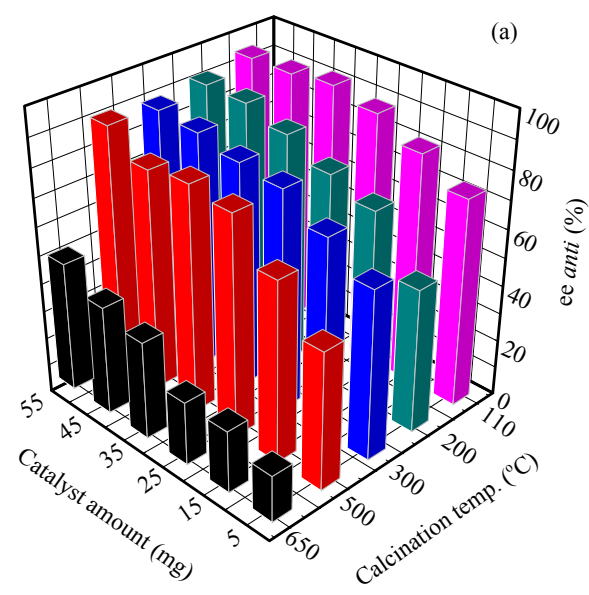

3.7.2. Effect of calcination temperature and magnetic solid acid amount

It is well known that the calcination temperature of the solid acid strongly affects the form of the $\mathrm{SO}_{4}{ }^{2-}$ group [14]. To investigate the influence of the calcination temperature and the amount of $\mathrm{SZF}_{3}$, the aldol reaction was performed under the optimized conditions. From Fig. 8, after calcining at $110{ }^{\circ} \mathrm{C}$, magnetic solid acid $\mathrm{SZF}_{3}$ gave the highest catalytic performance (>99\% yield, $92.1 \%$ ee anti, and anti/syn = 89/11). With increasing the calcination temperature from 110 to $650{ }^{\circ} \mathrm{C}$, the enantioselectivity and yield decreased for different amounts of catalyst $\mathrm{SZF}_{3}$ (5.0-55.0 mg). In particular, the enantioselectivity and yield of the aldol adduct sharply decreased when the calcination temperature reached $650{ }^{\circ} \mathrm{C}$. The main reason might be the removal of the $\mathrm{SO}_{4}{ }^{2-}$ group with increasing temperature, which was verified by the sharp mass loss at $600-780{ }^{\circ} \mathrm{C}$ (Fig. 2) and the decreased acidity of catalyst $\mathrm{SZF}_{3}-650$ (Fig. 3).

\subsubsection{Reaction with various substituted benzaldehydes}

Encouraged by the remarkable results under the above reaction conditions, the substrate scope was extended to a wide variety of benzaldehydes with ortho, meta, and para substituents. The catalytic results are summarized in Table 3. For the benzaldehydes with strong electron-withdrawing substituents $\left(\mathrm{R}=\mathrm{NO}_{2}\right.$ and $\mathrm{CN}$ ), the aldol reactions exhibited good to excellent enantioselectivity (86.0\%-95.6\% ee anti) and diastereoselectivity (anti/syn = 88-96/12-4) with 83\%-100\% yield (entries 1-6). However, the benzaldehydes with weak electron-withdrawing substituents $(\mathrm{R}=\mathrm{Cl}$ and $\mathrm{Br})$ gave moderate to good enantioselectivity $(70.9 \%-85.9 \%$ ee anti) and disappointing yield (19\%-76\%) although good to excellent diastereoselectivity (anti/syn $=88-96 / 12-4$ ) was achieved. Unfortunately, the benzaldehydes with electron-donating substituents $\left(\mathrm{R}=\mathrm{CH}_{3}\right.$ and $\left.\mathrm{OCH}_{3}\right)$ did not proceed smoothly.

\subsubsection{Recovery and reuse of catalyst}

At the end of the catalytic aldol reaction, magnetic solid acid $\mathrm{SZF}_{3}$ could be easily and quantitatively separated from the reaction mixture using an external magnet and directly reused in

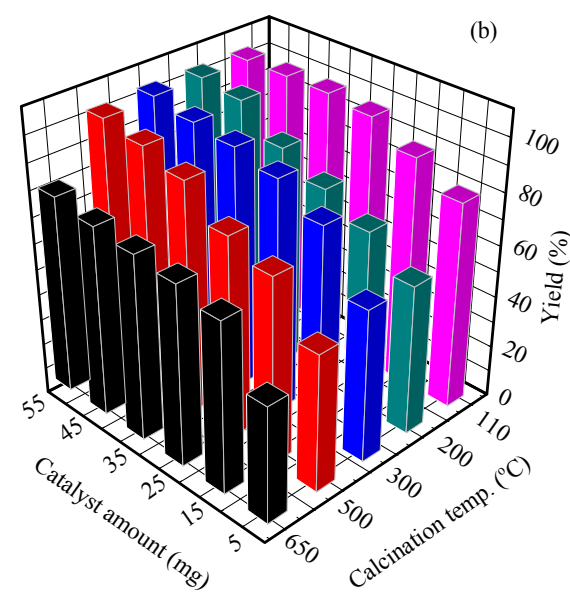

Fig. 8. Effect of calcination temperature and amount of $\mathrm{SZF}_{3}$ used on the enantioselectivity (a) and yield (b) of the aldol adduct. Reaction conditions: epi-CDNH 2 (11.0 mg, $0.0375 \mathrm{mmol}$ ), cyclohexanone (0.98 g, $10.0 \mathrm{mmol}), p$-nitrobenzaldehyde (76 mg, $0.50 \mathrm{mmol})$, and $2.0 \mathrm{~mL} \mathrm{H}_{2} \mathrm{O}$. 
Table 3

Asymmetric aldol reaction of various benzaldehydes with cyclohexanone.

\begin{tabular}{|c|c|c|c|c|}
\hline Entry & $\mathrm{R}$ & Isolated yield (\%) & ee $a n t i{ }^{b}(\%)$ & $\operatorname{Dr}(\text { anti/syn })^{\mathrm{b}}$ \\
\hline 1 & $4-\mathrm{NO}_{2}$ & $>99$ & 92.1 & $89 / 11$ \\
\hline 2 & $3-\mathrm{NO}_{2}$ & 95 & 90.9 & $81 / 19$ \\
\hline 3 & $2-\mathrm{NO}_{2}$ & 83 & 95.9 & $96 / 4$ \\
\hline 4 & 4-CN & 91 & 92.5 & $84 / 16$ \\
\hline 5 & $3-\mathrm{CN}$ & 94 & 86.0 & $88 / 12$ \\
\hline 6 & $2-\mathrm{CN}$ & 92 & 87.4 & $88 / 12$ \\
\hline 7 & $4-\mathrm{Cl}^{\mathrm{a}}$ & 76 & 72.8 & $94 / 6$ \\
\hline 8 & $3-\mathrm{Cl}$ a & 67 & 82.2 & $96 / 4$ \\
\hline 9 & $2-\mathrm{Cl}^{\mathrm{a}}$ & 38 & 81.9 & $93 / 7$ \\
\hline 10 & $2,4-\mathrm{Cl}$ a & 39 & 85.9 & $89 / 11$ \\
\hline 11 & $4-\mathrm{Br}^{\mathrm{a}}$ & 19 & 70.9 & $88 / 12$ \\
\hline
\end{tabular}

Reaction conditions: $\mathrm{SZF}_{3}(35.0 \mathrm{mg})$, epi- $\mathrm{CDNH}_{2}(11.0 \mathrm{mg}, 0.0375$ $\mathrm{mmol})$, cyclohexanone $(0.98 \mathrm{~g}, 10.0 \mathrm{mmol})$, benzaldehyde $(0.5 \mathrm{mmol})$ $\mathrm{H}_{2} \mathrm{O}(2.0 \mathrm{~mL}), 25^{\circ} \mathrm{C}, 48 \mathrm{~h}$.

a Reaction time 72 h. ${ }^{b}$ Determined by chiral HPLC (AD-H column).

cycle tests. Figure 9 shows the catalytic results of reused magnetic solid acid $\mathrm{SZF}_{3}$ in the aqueous asymmetric aldol reaction of cyclohexanone with 4-nitrobenzaldehyde. To our surprise, the yield and enantioselectivity unexpectedly increased during the first three cycles. In the third cycle, magnetic solid acid $\mathrm{SZF}_{3}$ produced the highest enantioselectivity $(94.7 \%$ ee anti) owing to the increased dispersion in the aqueous medium. It is noteworthy that $91.3 \%$ yield, $90.2 \%$ ee anti, and anti/syn $=78 / 22$ were obtained in the fifth run. The slight decrease in catalytic performance was because of the loss of $\mathrm{SO}_{4}{ }^{2-}$ (20.7 to 12.8 $\mathrm{wt} \%$ ) in the catalytic process.

\subsubsection{Large-scale asymmetric aldol reaction}

A large-scale asymmetric aldol reaction between cyclohexanone $(9.8 \mathrm{~g}, 0.10 \mathrm{~mol})$ and 4-nitrobenzaldehyde $(3.8 \mathrm{~g}$, $25 \mathrm{mmol}$ ) was performed at $25^{\circ} \mathrm{C}$ for $48-72 \mathrm{~h}$ in the presence

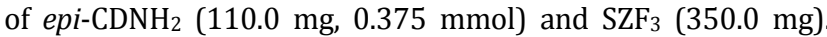
Good catalytic performance $(96 \%$ yield, anti $/$ syn $=90 / 10$, 93.2\% ee anti) was observed. After the completion of the aldol

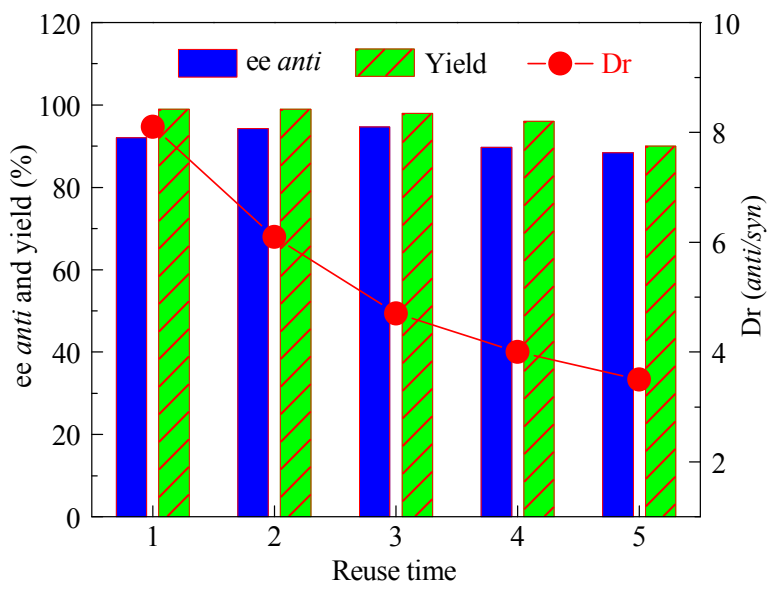

Fig. 9. Reusability of magnetic solid acid $\mathrm{SZF}_{3}$ in cycle experiment. reaction, solid acid $\mathrm{SZF}_{3}$ was filtered for reuse. Furthermore, epi-CDNH $\mathrm{CD}_{2}$ was also recovered by extraction with dilute hydrochloric acid (10\%), alkalization with an excess of concentrated ammonia, and extraction with $\mathrm{CH}_{2} \mathrm{Cl}_{2}$. The catalytic system could be reused and gave satisfactory results ( $87 \%$ yield, anti/syn $=89 / 11,90.4 \%$ ee $a n t i)$ in the third cycle.

\section{Conclusions}

With the purpose of realizing environmentally benign and friendly processes in asymmetric reactions, a series of sulfated zirconium hydroxide compounds loaded on nano- $\mathrm{Fe}_{3} \mathrm{O}_{4}$ were prepared, characterized, and applied in the aqueous asymmetric aldol reaction of various benzaldehydes with cyclohexanone for the first time. These magnetic solid acids, which could be easily and quantitatively separated from the reaction mixture using an external magnet, showed good to excellent catalytic performance for benzaldehydes with strong electronwithdrawing substituents and possessed good tolerance in five consecutive runs without a significant loss of catalytic performance.

\section{References}

[1] Casiraghi G, Battistini L, Curti C, Rassu G, Zanardi F. Chem Rev, 2011, 111: 3076

[2] Adachi S, Harada T. Eur J Org Chem, 2009: 3661

[3] Markert M, Mahrwald R. Chem Eur J, 2008, 14: 40

[4] Palomo C, Oiarbide M, Garcia J M. Chem Soc Rev, 2004, 33: 65

[5] Zali A, Ghani K, Shokrolahi A, Keshavarz M H. Chin J Catal (催化学 报), 2008, 29: 602

[6] Garro R, Navarro M T, Primo J, Corma A. J Catal, 2005, 233: 342

[7] Climent M J, Corma A, Fornes V, Guil-Lopez R, Iborra S. Adv Synth Catal, 2002, 344: 1090

[8] Kawal M, Onaka M, Izumi Y. Bull Chem Soc Jpn, 1988, 61: 1237

[9] Bhupathi R S, Devi B R, Dubey P K. Asian J Chem, 2011, 23: 4215

[10] Demuynck A L W, Peng L, de Clippel F, Vanderleyden J, Jacobs P A, Sels B F. Adv Synth Catal, 2011, 353: 725

[11] Polshettiwar V, Luque R, Fihri A, Zhu H B, Bouhrara M, Basset J M. Chem Rev, 2011, 111: 3036

[12] Zhang D H, Zhou C, Sun Z H, Wu L Z, Tung C H, Zhang T R. Nanoscale, 2012, 4: 6244

[13] Gawande M B, Branco P S, Varma R S. Chem Soc Rev, 2013, 42 : 3371

[14] Wang P C, Zhu J, Liu X, Lu T T, Lu M. ChemPlusChem, 2013, 78: 310

[15] Koukabi N, Kolvari E, Zolfigol M A, Khazaei A, Shaghasemi B S, Fasahati B. Adv Synth Catal, 2012, 354: 2001

[16] Wang Q H, Zhao W C, Sun X H, Zhao W J. Catal Lett, 2008, 121: 324

[17] Zillillah, Tan G W, Li Z. Green Chem, 2012, 14: 3077

[18] Lai D M, Deng L, Guo Q X, Fu Y. Energy Environ Sci, 2011, 4: 3552

[19] Lai D M, Deng L, Li J, Liao B, Guo Q X, Fu Y. ChemSusChem, 2011, 4: 55

[20] Kong A G, Wang P, Zhang H Q, Yang F, Huang S P, Shan Y K. Appl Catal A, 2012, 417-418: 183

[21] Chouhan G, Wang D S, Alper H. Chem Commun, 2007: 4809

[22] Hino M, Kobayashi S, Arata K. J Am Chem Soc, 1979, 101: 6439

[23] Lei T, Hua W M, Tang Y, Yue Y H, Gao Z. Chem J Chin Univ (雷霆, 华 伟明, 唐卧, 乐英红, 高滋. 高等学校化学学报), 2000, 21: 1697

[24] Hu Z J, Ling L C, Lü C X, Liu L, Zhang B J. Chin J Catal (胡子君, 凌立 成, 吕春祥, 刘朗, 张碧江. 催化学报), 1998, 19: 447

[25] Chang Z, Guo C X, Duan X, Zhang M L. Chin J Catal (常铮, 郭灿雄, 段 


\title{
Graphical Abstract
}

Chin. J. Catal., 2015, 36: 425-431 doi: 10.1016/S1872-2067(14)60222-9

\section{Aqueous asymmetric aldol reaction catalyzed by nanomagnetic solid acid $\mathrm{SO}_{4}{ }^{2-} / \mathrm{Zr}(\mathrm{OH})_{4}-\mathrm{Fe}_{3} \mathrm{O}_{4}$}

Tao Wu, Jingwei Wan, Xuebing Ma*

Southwest University

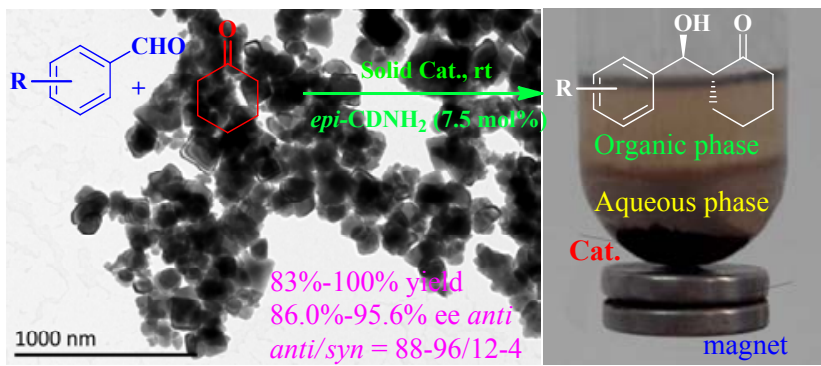

Sulfated zirconium hydroxide loaded on nano- $\mathrm{Fe}_{3} \mathrm{O}_{4}$ was prepared and applied to the aqueous asymmetric aldol reaction with good to excellent catalytic performance $(83 \%-100 \%$ yield, $86.0 \%-95.6 \%$ ee anti, and anti/syn $=88-96 / 12-4$ ).

雪, 张密林. 催化学报), 2003, 24: 47

[26] Zhang M L, Wang J, Mei C S, Jing X Y, Duan X. Chem J Chin Univ (张 密林, 王君, 梅长松, 景晓燕, 段雪. 高等学校化学学报), 2002, 23: 1347

[27] Wan J W, Ma X B, He R X, Li M. Chin Chem Lett, 2014, 25: 557

[28] Zhang J R, Gao L. Mater Lett, 2004, 58: 2730
[29] Ren B, Fan M Q Wang J, Jing X Y. Solid State Sci, 2011, 13: 1594

[30] Wan J W, Ding L, Wu T, Ma X B, Tang Q. RSC Adv, 2014, 4: 38323

[31] Zhou J Q, Wan J W, Ma X B, Wang W. Org Biomol Chem, 2012, 10: 4179

[32] Wang W, Ma X B, Wan J W, Cao J, Tang Q. Dalton Trans, 2012, 41: 5715

\section{纳米磁性固体酸 $\mathrm{SO}_{4}{ }^{2-} / \mathrm{Zr}(\mathrm{OH})_{4}-\mathrm{Fe}_{3} \mathrm{O}_{4}$ 催化水相不对称Aldol反应}

\author{
邬 涛, 万敬伟, 马学兵 ${ }^{*}$ \\ 西南大学化学化工学院, 重庆400715
}

摘要: 以纳米磁性材料 $\mathrm{Fe}_{3} \mathrm{O}_{4}, \mathrm{ZrOCl}_{2} \cdot 8 \mathrm{H}_{2} \mathrm{O}$ 和硫酸为原料, 在不同焙烧温度下制备了纳米磁性固体酸催化剂 $\mathrm{SO}_{4}{ }^{2-} / \mathrm{Zr}(\mathrm{OH})_{4}-\mathrm{Fe}_{3} \mathrm{O}_{4}$. 详细表征了该磁性固体酸的 $\mathrm{SO}_{4}{ }^{2-}$ 负载量、酸分布、表面形貌和孔结构等特性. 在含有硝基和氰基强吸电子基苯甲醛的不对称水 相Aldol反应中, $\mathrm{SO}_{4}{ }^{2-} \mathrm{Zr}(\mathrm{OH})_{4}-\mathrm{Fe}_{3} \mathrm{O}_{4}$ 表现出优良的催化性能 $(83 \%-100 \%$ 收率, 86.0\%-95.6\% ee anti和anti/syn = 88-96/12-4). 该类 磁性固体酸可在外加磁体作用下定量地从催化反应体系中分离并回收使用, 重复使用5次未见显著失活.

关键词：固体酸催化剂; 磁性; Aldol反应; 不对称催化; 水相

收稿日期: 2014-07-13. 接受日期: 2014-09-02. 出版日期: 2015-03-20.

*通讯联系人. 电话/传真: (023)68253237; 电子信箱: zcj123@swu.edu.cn

基金来源：国家自然科学基金(21071116).

本文的英文电子版由Elsevier出版社在ScienceDirect上出版(http://www.sciencedirect.com/science/journal/18722067). 